\title{
Modeling Price Volatility and Supply Response of Beef in Indonesia
}

\author{
Komalawati $^{a, *}$, R.W. Asmarantaka ${ }^{b}$, R. Nurmalina ${ }^{b}$, \& D.B. Hakim ${ }^{c}$ \\ ${ }^{a}$ Central Java Assessment Center for Agricultural Technology, Ministry of Agriculture \\ Bukit Tegalepek, Sidomulyo, PO BOX 101, Ungaran 50501, Jawa Tengah, Indonesia \\ bDepartment of Agribusiness, Faculty of Economic and Management, IPB University (Bogor Agricultural University) \\ 'Department of Economy, Faculty of Economic and Management, IPB University (Bogor Agricultural University) \\ Jalan Agatis, Kampus IPB Darmaga Bogor 16680, Indonesia \\ *Corresponding author: lalabptpitg@gmail.com \\ (Received 28-06-2018; Revised 08-11-2018; Accepted 31-12-2018)
}

\begin{abstract}
Beef is one of the strategic livestock commodities in Indonesia. As demand increases, the price of beef increases and tends to be volatile. The increased volatility in beef prices could influence production decision and the supply of beef. This study aimed to investigate the price volatility and the impact of price volatility on the supply response of beef in Indonesia. This study used secondary data obtained from various related institutions. Volatility was estimated using the GARCH $(p, q)$ model and the supply response model using OLS model. The empirical results indicated that among the estimated GARCH models, the GARCH $(2,3)$ seemed to be particularly appropriate to describe the beef price supply response. Beef price volatility in Indonesia was found to be low and persistent in the long run. Price uncertainty appeared to have a substantial negative effect on Indonesian beef production. The slow adjustment of farmers to demand and supply shocks indicate the importance of import as a temporary policy to fulfill the demand of beef in the short and medium-run.
\end{abstract}

\section{Keywords: beef; GARCH; price volatility; supply response; beef import}

\section{INTRODUCTION}

Beef is one of the strategic livestock commodities in Indonesia. Beef is the second source of animal protein $(21.27 \%)$ after chicken (58.02\%) (Ilham, 2009). As the awareness of the Indonesian people to the importance of protein for their healths increasing, the demand for beef also increases (Ariningsih 2014). From 2006 to 2015, demand for beef increased with the average growth rate of $4.08 \%$ per year (Pusdatin, 2016). On the other hand, the growth of beef cattle population as well as the production of beef increased only $4.05 \%$ and $3.14 \%$ per year, respectively, during the same periods (Pusdatin, 2016). The data show that the population and the production of beef have a lower growth rate compared to the growth of demand and thus, it increases the excess demand for beef.

The excess demand for beef has increased the price of beef. Recently, the increasing price of beef is quite uncertain or volatile. This could be seen from the coefficient of variation $(\mathrm{CV})$ value of beef price which is around 0.25 . The price of beef tend to be more volatile especially during Eid Al-Fitr and Eid Al-Adha. Furthermore, the price of beef tend to be volatile since it is an import commodity and thus, it is vulnerable to the changes in price either in the country or in the exporter countries. Prastowo et al. (2008) through their study have found that the price of beef is influenced by demand in Eid Al-Fitr and Eid Al-Adha, as well as the international price. Komalawati et al. (2018) found that factors influencing the volatility of beef price is on the supply side including the quantity of imported feeder cattle.

The volatility of beef price become important since it influences the volatility of other commodities' prices. Prastowo et al. (2008) mention in their study that beef is one of volatile foods and it can significantly influence the inflation of the other commodities. On the other hand, volatility can also be defined as an uncertainty in the price movement or price risk that every producer has to face. As for beef in Indonesia, producers could be categorized as small scale farmers with traditional management and medium and large scale farmers (feedlotter) with comercial orientation. For small scale farmers with traditional cattle rearing, price volatility or price risk do not influence their production decision since they use their cattle as savings (Zainuddin et al., 2015). Meanwhile, for medium and large scale farmers (feedlotter) with commercial orientation and daily production, price volatility could probably influence their production decision.

A rational producers will maximize their profits. However, when the price fluctuation is uncertain, the producers cannot maximize their profits, but they will try to maximize their returns in the form of income and safety (Ajetomobi, 2010). If the price risk has significantly influenced producers' decision on production, price volatility becomes very important in influencing 
the supply of agricultural commodities (Rezitis \& Stavropoulos, 2009).

There are many studies on estimating supply response to prices (Rahji \& Adewumi, 2008; Rezitis \& Stavropoulos 2009, 2010; Kuwornu et al., 2011; Ozkan et al., 2011; Gosalamang et al., 2012; Zainuddin et al., 2015; Bhattacharya et al., 2016; Uchezuba \& Mbai, 2016; Ehirim et al., 2017). However, the majority of the previous empirical literature still focuses only to prices at the producer level and does not consider the price volatility and price risk. The price volatility and price risk are rarely included because it has not been considered as an important factor. However, since the price of beef tends to be volatile recently in Indonesia, it becomes important to assess the response of producer to price volatility and price risk.

Some studies on price volatility and supply response of beef use producer prices as the expected price (Rezitis \& Stavropoulos, 2009, 2010; Uchezuba \& Mbai, 2016). In this article, it uses the consumer prices as the expected price, while the producer prices uses as additional explanatory variables. The previous researches also used only one variable of price volatility (Rezitis \& Stavropoulos, 2009, 2010; Uchezuba \& Mbai, 2016). This article uses two variables of price volatility based on the fattening period of imported feeder cattle and local feeder steer. Therefore, the objective of this paper is to analyse the volatility of beef price and explore the supply response in the beef industry of Indonesia. Other parameters, such as the quantity of imported beef, the price of milk and the price of chicken are used to describe the appropriate supply response model and illustrate producers' risk.

\section{METHODS}

An econometric model to analyse supply response of agricultural products using time series data was developed by Nerlove in 1956 and then Nerlove and Bachman in 1960 (Gosalamang et al. 2012). Supply response model is a dynamic model or an autoregressive model because it includes the lagged values of the dependent (output) variables among its explanatory variables and the lagged values of the independent variables (Gosalamang et al., 2012).

The model is also well known as an adjustment model since in the production process of the agricultural commodity, farmers cannot instantly adjust to any sudden changes in supply and demand factors. Therefore, the first assumption of the model is the producers or farmers will adjust their output $Y_{t}$ to the desired or optimum level $Y_{t}^{*}$ (Gosalamang et al., 2012). The adjustment process to the desired level may not be attained instantaneously, but gradually over a sequence of time periods. It sometimes requires to adjust because of adjustment cost and fixed assets (Leaver, 2004) or because of technological constraints, institutional limitations, technical delays, and biological factors (Gosalamang et al., 2012). Therefore, the output adjustment achieved in any period is assumed to be a proportion or a fraction $(\beta)$ of the difference between the desired output $\left(Y_{t}^{*}\right)$ and the previous period's output $\left(Y_{t-1}\right)$ (Gosalamang et al., 2012), and it is specified as:

$$
Y_{t}-Y_{t-1}=\beta\left(Y_{t}^{*}-Y_{t-1}\right) \quad \beta \epsilon[0,1]
$$

$\beta$ is an adjustment coefficient with the range value between zero and one. If the value of $\beta=1$, the farmers are able to adjust to supply and demand shocks in one period fully and $Y_{t}^{*}=Y_{t}$. On the other hand, $\beta=0$ implies that there is no adjustment and $Y_{t}=Y_{t-1}$. An estimated value of $\beta$ close to one indicates an immediate adjustment to supply and demand shocks. On the contrary, an estimate of $\beta$ close to zero implies a very slow adjustment to changes in supply and demand shocks or exogenous variables.

The second assumption states that farmers will revise the price they expect to prevail in the coming year in proportion to the error they made in predicting price in the current year (Gosalamang et al., 2012). If the expected price in the current year is denoted by $P_{t}^{*}$, the expected price in the previous period by $P_{t-1}^{*}$, the actual price in the previous period by $P_{t-1}$, and the proportion of the error by which farmers revise their expectations, by a constant $\delta$ which lies between zero and one, the assumption will be specified as follows:

$$
P_{t}^{*}-P_{t-1}^{*}=\delta\left(P_{t-1}-P_{t-1}^{*}\right) \quad \delta \in[0,1]
$$

The third assumption, the desired supply is difficult to observe or predict. It must be expressed as a function of variables that can be observed (Gosalamang et al., 2012). Hence, Nerlove simplified the model by formulating the desired output $\left(Y_{t}^{*}\right)$ as a linear function of its expected price $P_{t}^{*}$, and other exogenous variables $Z_{t}$. Thus, the third assumption may be written as follows:

$\mathrm{Y}_{\mathrm{t}}^{*}=\alpha_{0}+\alpha_{1} \mathrm{P}_{\mathrm{t}}^{*}+\alpha_{2} \mathrm{Z}_{\mathrm{t}}+\mathrm{U}_{\mathrm{t}}$

Substituting (3) into (1), one obtains:

$Y_{t}-Y_{t-1}=\beta\left[\left(\alpha_{0}+\alpha_{1} P_{t}^{*}+\alpha_{2} Z_{t}+U_{t}\right)-Y_{t-1}\right]$

$Y_{t}=\beta \alpha_{0}+\beta \alpha_{1} P_{t}^{*}+\beta \alpha_{2} Z_{t}+\beta U_{t}+(1-\beta) Y_{t-1}$

$Y_{t}=\pi_{0}+\pi_{1} P_{t}^{*}+\pi_{2} Z_{t}+\pi_{3} Y_{t-1}+\omega_{t}$

where $Y_{t}$ is the output production, $\mathrm{P}_{t}^{*}$ is the expected price, $\mathrm{Y}_{\mathrm{t}-1}$ is the output produced in the previous period, $Z_{t}$ is the exogenous variables, $\omega_{t}$ or is a mean zero normally distributed error term with variance $\sigma_{11}, \pi_{0}-\pi_{3}$ are parameter coefficients with $\pi_{0}=\beta \alpha_{0^{\prime}} \pi_{1}=\beta \alpha_{1,} \pi_{2}=$ $\beta \alpha_{2}$, and $\pi_{3}=(1-\beta)$.

By incorporating price risk or price volatility $\left(\sigma_{t}\right)$ variable, the response supply equation model can be described as:

$Y_{t}=\pi_{0}+\pi_{1} P_{t}^{*}+\pi_{2} \sigma_{t}+\pi_{3} Z_{t}+\pi_{4} Y_{t-1}+\omega_{t}$

where $\pi_{0}-\pi_{4}$ are parameter coefficients with $\pi_{0}=\beta \alpha_{0^{\prime}} \pi_{1}$ $=\beta \alpha_{1}, \pi_{2}=\beta \alpha_{2}, \pi_{3}=\beta \alpha_{3^{\prime}}$ and $\pi_{4}=(1-\beta)$.

The expected price is also difficult to observe. In this study, the expected price used a simple model which was also used by Nerlove and known as naive expectations model. In this model, the expected price $\left(\mathrm{P}_{\mathrm{t}}^{*}\right)$ is defined as past market price $\left(\mathrm{P}_{\mathrm{t}-1}\right)$. Therefore, the equation (7) could be depicted as follows: 
$Y_{t}=\pi_{0}+\pi_{1} P_{t-1}+\pi_{2} \sigma_{t}+\pi_{3} Z_{t}+\pi_{4} Y_{t-1}+\omega_{t}$

Beef price volatility $\left(\sigma_{t}\right)$ in this study was estimated using GARCH model that was introduced initially by Bollerslev (1986). GARCH model in this study was developed from the mean equation AR, MA, or ARIMA chosen according to the highest value of log likelihood, and the smallest value of Schwarz Information Criteria (SIC) and Akaike Information Criteria (AIC). The mean equation model was evaluated using ARCH-LM heteroscedasticity test (Lagrange Multiplier for Autoregressive Conditional Heteroscedasticity/ARCH test). The mean equation was proceed using GARCH model when the residual was heterogeneous. The GARCH model was specified as follows:

$\sigma_{t}^{2}=\alpha_{0}+\alpha_{n} \varepsilon_{t-n}^{2}+\lambda_{n} \sigma_{t-n}^{2}$

where $\sigma_{t}^{2}$ was conditional variance, $\varepsilon_{t-n}^{2}$ was squared residual in period $t-n, \sigma_{t-n}^{2}$ was conditional variance in period t-n, and $\alpha_{0}, \alpha_{1}, \lambda_{1}$ were parameter coefficients.

The best model was chosen based on the highest value of $\log$ likelihood, and the smallest value of AIC and SIC. $\alpha_{1}$ was an $\mathrm{ARCH}$ effect and could indicate whether the price volatility was higher or lower. The sum of $\alpha_{n}$ and $\lambda_{n}$ less than one indicates the persistence behavior of price volatility. The value of beef price volatility $\left(\sigma_{t}\right)$ used in the supply response model was a conditional standard deviation that was generated from the square root of conditional variance $\sigma_{t}^{2}$. GARCH model was estimated using Maximum Likelihood approach and analysed using Eviews 7.

\section{Data and Model Specification}

Data used in this study were monthly time series during the period of January 2008 to December 2016, except for price data which were a daily time series from 5 January 2008 to 31 December 2016. In particular, daily price data of beef were obtained from the Ministry of Trade. The price of of milk and the price of chicken were obtained from Central Bureau of Statistics (BPS). In Rezitis \& Stavropoulos (2009; 2010), Gosalamang et al. (2012), and Uchezuba \& Mbai (2016), the prices of inputs such as medicine and feed were included in the model. In Indonesia, those inputs wereeither not published or not recorded well. Therefore, in this model, there is no inputs included. All variables were then transformed into logarithms, and all prices were deflated by the consumer price index $(2012=100)$.

The beef supply response model in equation (8) was specified as:

$Y_{t}=\pi_{0}+\pi_{1} P_{b t-1}+\pi_{2} P_{p t-1}+\pi_{3} \sigma_{t-4}+\pi_{4} \sigma_{t-36}+\pi_{5} M_{i t-1}+\pi_{6} P_{s t-1}+$

$\pi_{7} P_{c t-n}+\pi_{8} Y_{t-1}+\omega_{t}$

$\pi_{1}, \pi_{2}, \pi_{6}, \pi_{7}, \pi_{8}>0 ; \pi_{3}, \pi_{4}, \pi_{5}<0$

Where $Y_{t}$ was beef production which was proxied by the slaughter rate (head/month). $\mathrm{P}_{\mathrm{t}-1}$ was the expected real consumer price of beef in time $t$ which was defined as the past market price (IDR/kg/month) and $\mathrm{P}_{\mathrm{pt}-1}$ was the real producer price of beef (IDR/kg live cattle/month). $\sigma_{t-4}$ was the price volatility or price risk in time $t-4$ and $\sigma_{t-36}$ was the price volatility or price risk in time $t-36 . M_{i t-1}$ was the quantity of beef imported in the previous period $(\mathrm{t}-1)$ (tonnes/month). $\mathrm{P}_{\mathrm{st}-1}$ was the price of milk price in time $\mathrm{t}-1$ (IDR/litre/month); and $\mathrm{P}_{\mathrm{pt}-1}$ was the price of chicken in time $\mathrm{t}-1$ (IDR/ $/ \mathrm{kg} / \mathrm{month}) . \mathrm{Y}_{\mathrm{t}-1}$ was the beef production or slaughter rate in period $\mathrm{t}-1$ (head/month). It is important to note that the coefficient parameter for the last variable was incorporated the adjustment coefficient (1- $\beta$ ), and thus, the coefficient adjustment would be $\beta=1-\pi_{9}$.

Farmers in this study were cattle rearers in general, but specifically large scale farmers such as feedlotters who were able to produce beef on day to day basis. The expected beef price used in this study was the beef price at the consumer level. The consumer beef price used as the expected beef price since it differed from the producer and the imported beef price, specifically during the examined period. The consumer beef price is usually higher than the imported beef price because of the preferences of Indonesian consumer who tend to prefer domestic meat products. Meanwhile, the producer beef price was also included in order to understand the behavior of small scale cattle owners to the fluctuation of the price of live cattle.

$\sigma_{t-n}$ as the price volatility was considered to be important risk factors, and thus, it was included. According to The Regulation of Ministry of Agriculture No. 7, 2008, the feeder steer could only be imported with the maximum weight of 350 kilograms and with this maximum weight, it needed 3 to 4 months period of fattening. Therefore, a 4 month lag period was used in this study. This was also supported by the significant influence of the imported feeder cattle from four previous period to price volatility in Indonesia (Komalawati et al., 2018). A 36 months lag period was also used for the volatility variable because it took three years or 36 months period to prepare the local cattle from breeding until it was ready to slaughter (Harmini et al., 2011). The fattening period of imported cattle was used because most farmers in large or medium scale or feedlotter prefered to use imported cattle for production continuity and maintaining profit. Meanwhile the 36th lag period was used because the supply of beef in Indonesia was not coming only from the imported feeder cattle, but also from the local cattle. The quantity of imported beef from the previous period ( $t-1)$ was used because the imported beef would influence the availability of beef and it was expected to influence the slaughter rate. The increasing quantity of imported beef in the previous period was expected to decrease the slaughter rate of cattle.

The price of milk, $\mathrm{P}_{\mathrm{s}^{\prime}}$ was used because it was a phenomenon for farmers in Indonesia who had dairy cattle to slaughter the cattle and sold it in the beef market (Zainuddin et al., 2015). This happened to prevent them from loss because of the decreasing price of milk. Meanwhile, the price of chicken, $\mathrm{P}_{p^{\prime}}$ was also used in this study because chicken was a substitution product for beef. The increasing price of chicken would change consumer preferences to beef (Kusriatmi, 2014). The increasing demand for beef would motivate beef producers to increase their supply of beef. In the 
other words, there was a indirect relationship between the quantity of beef supplied and the price of chicken which was positively correlated (Zainuddin et al., 2015). Supply response equation was analysed using Ordinary Least Square (OLS) technique and software Eviews 7.

\section{RESULTS}

Figure 1 illustrates different data of prices. As could be seen from Figure 1, the consumer price of beef was higher compared to the other prices. The movement of beef price in the consumer level was almost similar to those in the producer level, but relatively different to the other prices. Among those prices, the price of chicken was more fluctuate. The CV for the price of chicken was the highest which was around 0.12. It was followed by the price of beef at the producer level, the price of milk, and the price of beef at the consumer level with the value of CV subsequently around $0.10,0.09,0.09$. These prices were subsequently analysed using Augmented Dickey-Fuller (ADF) test. Table 1 provides the results of unit root tests which were analyzed using ADF test. According to Table 1, all variables in the supply response equation were stationary at the first difference.

Table 1 provides the results of unit root tests which were analysed using ADF test. According to Table 1, the majority variables were stationary at the first difference except for the price of chicken. Since the unit root tests analysed using the critical values $1 \%$, the price of chicken was also stationary at the first difference. Therefore, it could be concluded that all variables in the supply response equation were stationary at the first difference.

The price data were in real data with the basic year of 2012, and transformed into a natural logarithm to clear the data from inflation, trend, and seasonal effect. Therefore, volatility measurement only used the unpredicted part of the price. The initial step of volatility measurement was to determine the mean model. The best mean equation was MA(1) model. The model was substantially tested by using ARCH-LM test, and it had a significant probability value $(p<0.01)$. It implied an $\mathrm{ARCH}$ effect in the mean equation model of MA(1). This meant the model could be estimated using GARCH model.

Table 2 presents the estimated parameters of beef price volatility model for different models of GARCH $(p, q)$. According to several models of GARCH $(p, q)$ that was analysed, GARCH $(2,3)$ was chosen as the best model since it had the highest value of log likelihood and the smaller value of AIC and SIC. Furthermore, this model had the significant value of parameter coefficient of the mean equation and GARCH model. ARCH-LM test in GARCH $(2,3)$ showed that there was no ARCH in the GARCH model and the model had already well specified.

The estimation result of GARCH $(2,3)$ model showed that the coefficient value of $\mathrm{ARCH}$ or residual squares $(\alpha)$ was 0.06 . This implied that the price of beef had low price volatility. The value of the parameter coefficient GARCH $(\beta)$ was close to one. This indicated the persistence of shock that was occurred in the variance. A smaller $\alpha$ value than the value of $\beta$ illustrated the move-

Table 1. Results of unit root tests using Augmented DickeyFuller (ADF) test

\begin{tabular}{cccc}
\hline Variables & Level & $\begin{array}{c}\text { First } \\
\text { difference }\end{array}$ & $\begin{array}{c}\text { Critical } \\
\text { values } 1 \%\end{array}$ \\
\hline $\mathrm{Y}$ & -2.355 & $-4.309^{* * *}$ & -3.496 \\
& $(0.159)$ & $(0.001)$ & \\
$\mathrm{Pb}$ & -0.081 & $-8.854^{* * *}$ & -3.492 \\
& $(0.948)$ & $(0.000)$ & \\
$\mathrm{Pp}$ & -1.240 & $-10.140^{* * *}$ & -3.493 \\
& -0.655 & $(0.000)$ & \\
$\mathrm{Ps}$ & -1.917 & $-10.083^{* * *}$ & 3.492 \\
& -0.324 & $(0.000)$ & \\
$\mathrm{Pc}$ & -2.686 & $-8.617^{* * *}$ & -3.493 \\
& $(0.079)$ & $(0.000)$ & \\
$\mathrm{Mi}$ & 0.662 & $-8.977^{* * *}$ & -3.494 \\
& -0.991 & $(0.000)$ & \\
\hline
\end{tabular}

Note: ${ }^{* * *}=$ significant at $1 \%$

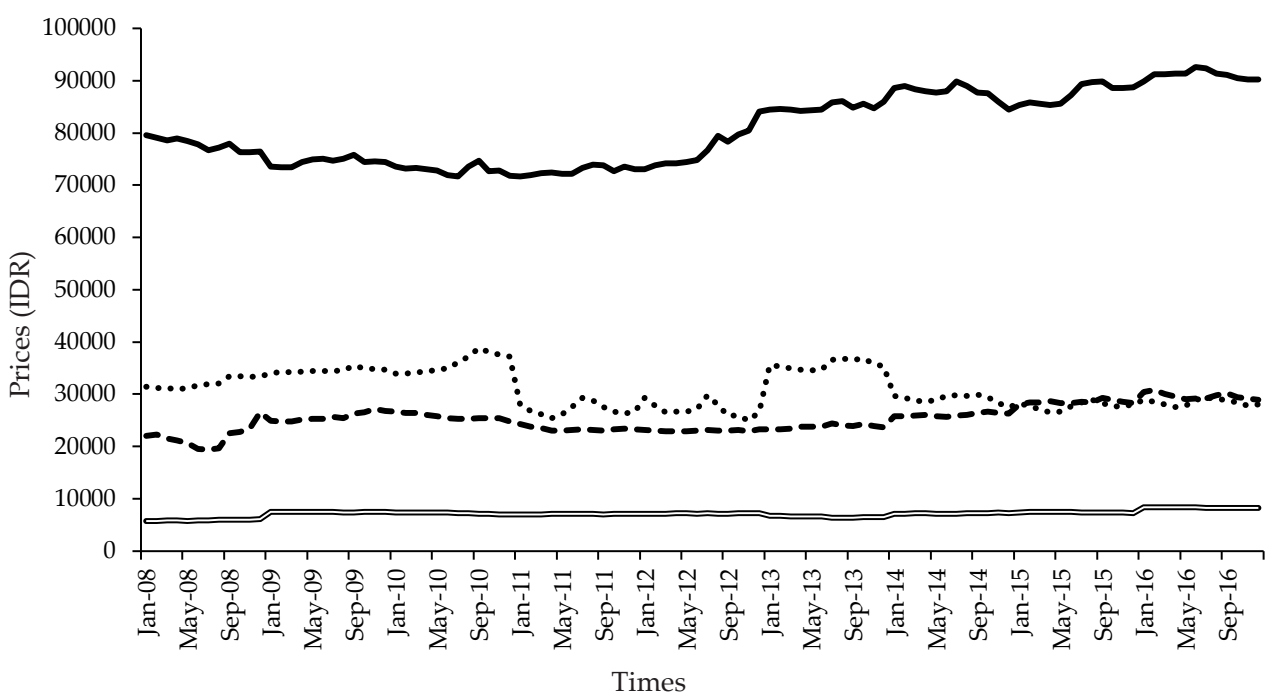

Figure 1. The fluctuation of price variables in the model; $-=$ cons price (IDR/kg), --- = prod price (IDR/kg), $==$ milk price (IDR/ $\mathrm{kg}), \cdots=$ chicken price (IDR/kg). 
Table 2 . The estimation results of beef price volatility analysis

\begin{tabular}{|c|c|c|c|c|c|c|c|c|c|}
\hline & $\begin{array}{c}\text { GARCH } \\
(1,1)\end{array}$ & $\begin{array}{c}\text { GARCH } \\
(1,2)\end{array}$ & $\begin{array}{c}\text { GARCH } \\
(1,3)\end{array}$ & $\begin{array}{c}\text { GARCH } \\
(2,1)\end{array}$ & $\begin{array}{c}\text { GARCH } \\
(2,2)\end{array}$ & $\begin{array}{c}\text { GARCH } \\
(2,3)\end{array}$ & $\begin{array}{c}\text { GARCH } \\
(3,1)\end{array}$ & $\begin{array}{c}\text { GARCH } \\
(3,2)\end{array}$ & $\begin{array}{c}\text { GARCH } \\
(3,3)\end{array}$ \\
\hline $\mathrm{MA}(1)$ & $\begin{array}{c}0.194 \\
(0.000)\end{array}$ & $\begin{array}{c}0.176 \\
(0.000)\end{array}$ & $\begin{array}{c}0.173 \\
(0.000)\end{array}$ & $\begin{array}{c}0.194 \\
(0.000)\end{array}$ & $\begin{array}{c}0.194 \\
(0.000)\end{array}$ & $\begin{array}{c}0.223 \\
(0.000)\end{array}$ & $\begin{array}{c}0.199 \\
(0.000)\end{array}$ & $\begin{array}{c}0.208 \\
(0.000)\end{array}$ & $\begin{array}{c}0.229365 \\
(0.000)\end{array}$ \\
\hline$\alpha_{0}$ & $\begin{array}{c}2.44 \mathrm{E}-06 \\
(0.000)\end{array}$ & $\begin{array}{c}2.88 \mathrm{E}-06 \\
(0.000)\end{array}$ & $\begin{array}{c}3.23 \mathrm{E}-06 \\
(0.000)\end{array}$ & $\begin{array}{c}2.15 \mathrm{E}-07 \\
(0.000)\end{array}$ & $\begin{array}{c}1.94 \mathrm{E}-07 \\
(0.000)\end{array}$ & $\begin{array}{c}1.86 \mathrm{E}-07 \\
(0.000)\end{array}$ & $\begin{array}{c}2.07 \mathrm{E}-07 \\
(0.000)\end{array}$ & $\begin{array}{c}2.66 \mathrm{E}-07 \\
(0.000)\end{array}$ & $\begin{array}{c}1.83 \mathrm{E}-07 \\
(0.000)\end{array}$ \\
\hline$\alpha_{1}$ & $\begin{array}{c}0.378 \\
(0.000)\end{array}$ & $\begin{array}{c}0.453 \\
(0.000)\end{array}$ & $\begin{array}{c}0.84 \\
(0.000)\end{array}$ & $\begin{array}{c}0.631 \\
(0.000)\end{array}$ & $\begin{array}{c}0.588 \\
(0.000)\end{array}$ & $\begin{array}{c}0.568 \\
(0.000)\end{array}$ & $\begin{array}{c}0.565 \\
(0.000)\end{array}$ & $\begin{array}{c}0.557 \\
(0.000)\end{array}$ & $\begin{array}{c}0.528 \\
(0.000)\end{array}$ \\
\hline$\alpha_{2}$ & & & & $\begin{array}{l}-0.563 \\
(0.000)\end{array}$ & $\begin{array}{l}-0.528 \\
(0.000)\end{array}$ & $\begin{array}{l}-0.509 \\
(0.000)\end{array}$ & $\begin{array}{l}-0.441 \\
(0.000)\end{array}$ & $\begin{array}{l}-0.247 \\
(0.000)\end{array}$ & $\begin{array}{l}-0.461 \\
(0.000)\end{array}$ \\
\hline$\alpha_{3}$ & & & & & & & $\begin{array}{l}-0.061 \\
(0.000)\end{array}$ & $\begin{array}{l}-0.228 \\
(0.000)\end{array}$ & $\begin{array}{l}-0.012 \\
(0.829)\end{array}$ \\
\hline$\lambda_{1}$ & $\begin{array}{c}0.542 \\
(0.000)\end{array}$ & $\begin{array}{c}0.318 \\
(0.000)\end{array}$ & $\begin{array}{c}0.016 \\
(0.000)\end{array}$ & $\begin{array}{c}0.931 \\
(0.000)\end{array}$ & $\begin{array}{c}1.007 \\
(0.000)\end{array}$ & $\begin{array}{c}1.137 \\
(0.000)\end{array}$ & $\begin{array}{c}0.934 \\
(0.000)\end{array}$ & $\begin{array}{c}0.656 \\
(0.000)\end{array}$ & $\begin{array}{c}1.134 \\
(0.000)\end{array}$ \\
\hline$\lambda_{2}$ & & $\begin{array}{c}0.138 \\
(0.000)\end{array}$ & $\begin{array}{l}-0.007 \\
(0.022)\end{array}$ & $(0.000)$ & $\begin{array}{l}-0.069 \\
(0.000)\end{array}$ & $\begin{array}{l}-0.288 \\
(0.000)\end{array}$ & (0.000) & $\begin{array}{c}0.259 \\
(0.000)\end{array}$ & $\begin{array}{l}-0.289 \\
(0.008)\end{array}$ \\
\hline$\lambda_{3}$ & & & $\begin{array}{c}0.258 \\
(0.000)\end{array}$ & & & $\begin{array}{c}0.091 \\
(0.000)\end{array}$ & & & $\begin{array}{c}0.097 \\
(0.000)\end{array}$ \\
\hline$\alpha+\lambda$ & 0.920 & 0.909 & 1.107 & 0.999 & 0.998 & 0.999 & 0.997 & 0.997 & \\
\hline $\begin{array}{l}\text { Log } \\
\text { likelihood }\end{array}$ & 14368.58 & 14375.7 & 14458.88 & 14553.96 & 14558.40 & 14574.67 & 14559.87 & 14565.18 & 14574.78 \\
\hline AIC & -8.751 & -8.755 & -8.805 & -8.863 & -8.865 & -8.875 & -8.866 & -8.869 & -8.874 \\
\hline SIC & -8.743 & -8.745 & -8.794 & -8.854 & -8.854 & -8.862 & -8.855 & -8.856 & -8.859 \\
\hline
\end{tabular}

Table 3. Results of the beef supply response model

\begin{tabular}{|c|c|c|}
\hline Variables & Coefficient & Prob. \\
\hline Constant & 1.662 & 0.355 \\
\hline Beef price $t-1$ & -0.050 & 0.696 \\
\hline Producer price $\mathrm{t}-1$ & -0.041 & 0.778 \\
\hline Beef price volatility t- 4 & $-0.029^{*}$ & 0.073 \\
\hline Beef price volatility $\mathrm{t}-36$ & -0.030 & 0.109 \\
\hline Imported meat $\mathrm{t}-1$ & $-0.019^{* *}$ & 0.044 \\
\hline Milk price $\mathrm{t}-1$ & 0.054 & 0.750 \\
\hline Chicken price $\mathrm{t}-1$ & -0.024 & 0.762 \\
\hline The slaughter rate $\mathrm{t}-1^{\mathrm{a}}$ & $0.916^{* * *}$ & 0.000 \\
\hline R-squared & 0.830 & \\
\hline
\end{tabular}

Note: Dependent variable $=$ slaughter number, ${ }^{* * *}, * *, *=$ significant at $1 \%, 5 \%$, and $10 \%$ respectively; (a) parameter coefficient $=(1-\beta)$.

ment of beef prices which was more influenced by its variance than the external turmoil or dynamic markets. The sum of $\alpha$ and $\beta$ values that closed to one indicate the volatility of beef price tended to persist for a long time. This assumption was supported by the study of Burhani et al. (2013) that had come to similar conclusion that the price of beef was volatile and persistent.

The volatility value was obtained from the estimation of GARCH (2.3) model, and it was used in the supply response model. Table 3 presents the estimated parameters of the supply response equation of the $\operatorname{GARCH}(2,3)$ model. Table 3 shows that the regression equation of supply response model has the determination coefficient $\left(R^{2}\right)$ of 0.830 . This indicated that $83 \%$ of the variation of the meat supply response model could be predicted based on variations in the value of explana- tory variables. Most of the parameter coefficients had the theoretically expected signs except for beef price in the producer and consumer level, as well as the price of chicken from the previous period. The majority estimated coefficiens were not significant at all levels except for the beef price volatility from four previous periods, the imported meat from a month before, and the slaughter rate from previous period.

\section{DISCUSSION}

Theoretically, the price is a market signal for producers in determining the allocation of input and output produced. However, in reality, there are the other factors that can influence or inhibit producers from detecting the market signal. Therefore, the variables used in the supply response equation are not only the expected price and the price risk but also the other variables such as the quantity of beef imported, the price of the other commodity produced from similar input (milk price), and the price of beef substitution (the price of chicken).

According to the empirical results, the estimated coefficient of both consumer and producer price are small and negative or inelastic, indicating that both prices of beef either in the consumer or in the producer level do not influence the slaughter rate. According to Gosalamang et al. (2012) and Rezitis \& Stavropoulos $(2009,2010)$, the negative price elasticity of beef supply response is possible because cattle is used as consumer goods and capital goods. As in the other developing countries such as in Botswana, cattle farms in Indonesia are mostly subsistence or not intended for commercial purposes and use cattle as their savings (Harmini et al., 
2011; Zainuddin et al., 2015). Therefore, farmers do not have a regular sales plan but instead follow the needs or when market conditions are excellent. In some regions, farmers even use cattle as part of their culture and prestige, and thus, they will not easily sell their cattle even when the prices in the consumer or producer level increase.

On the other hand, for commercial farmers, the negative value of the estimated coefficient of both consumer and producer prices implies the behavior of the farmers who will undoubtedly retain the number of slaughtered cattle in the coming period if the increase in beef prices is considered permanent and sustainable. The slaughter number of cattle are specifically for the slaughtered female cattle in order to produce more cattle breeds and increase the population in the future. Therefore, the negative value of price elasticity on the supply of meat commodities is expected to increase the populations and production in the future (Rezitis \& Stavropoulos, 2010). In the other words, the commercial farmers will reduce the slaughter rate in this period in order to have more benefits in the future.

The volatility of beef prices in the four previous periods affected the slaughter rate negatively $(\mathrm{p}<0.10)$ with the value of parameter coefficient of -0.029 (Table 3). Meanwhile, the volatitility of beef prices with 36 periods of lag did not significantly affect the slaughter rate but it had almost similar value to the coefficient parameter of the volatility of beef prices of the four previous periods (-0.030) (Table 3). The value of beef price volatility elasticity to supply response was smaller from the value of the beef price volatility elasticity obtained by Uchezuba \& Mbai (2016) with a magnitude of about -0.0479 with regard to the beef industry in Namibian, as well as Rezitis \& Stavropoulos (2009) with a magnitude of about -0.060 with regard to the beef industry in Alberta, Canada. Rezitis \& Stavropoulos (2010) find another higher value with a magnitude of about -0.164 and -0.145 for price risk elasticity pork and beef industry in Greece, respectively. Those two studies used price volatility from the previous and current period.

The sign for elasticity value of price volatility either from four previous periods or thirty six months before to supply response was negative. The negative value of elasticity means the slaughter number will increase when price volatility or price risk decreases. While the volatility of beef prices in the four previous periods was related to the imported feeder cattle, the volatility of beef prices from the thirty six previous periods was more related to the local cattle owned by local farmers. The insignificant value of the volatility from the thirty six previous periods had proven that the slaughter rate was more influenced by the imported feeder cattle than the local cattle. This statement is supported by Komalawati et al. (2018) who find that the price volatility of beef is significantly influenced by the quantity of imported feeder cattle than local cattle.

The result justifies the study of Narundhana et al. (2016) who found the positive and direct relationships between the slaughter rate and the price of imported feeder steer. The feedlotters and traders will decide their slaughter rate according to the price of imported feeder steer. According to Tseuoa et al. (2012), the feedlotters prefer to buy imported beef price because: (1) the price and the transportation cost of imported feeder cattle is cheaper; (2) it is easy to obtain a large number of imported feeder cattle as compared to the local ones; and (3) the time for sending the imported feeder catlle is faster compared to the local feeder cattle from Nusa Tenggara Timur, Nusa Tenggara Barat, dan Sulawesi Selatan (Tseuoa et al. 2012). Therefore, with the high price of beef, the decreasing price of imported feeder steer will increase the slaughter rate (Narundhana et al., 2016).

The significant influence of the price volatility of imported feeder cattle to the slaughter rate is reasonable considering the behavior of local farmers and the large scale farmers or feedlotters. Local farmers are usually small farmers who have small scale production, live in the rural areas, and have difficulty in developing the production of beef due to their resource limitation (Kalangi et al., 2014; Pambudy, 2018). Meanwhile, feddlotters are medium to large scale farmers who commercially raise their cattle to produce beef in high scale and could have the ability to produce beef in day to day basis. Furthermore, Kusriatmi et al. (2014) stated that the production of beef coming from fattening of imported feeder cattle could be categorized as domestic production since it was the value added of the production process in Indonesia. However, the low and negative value of supply price volatility elasticity shows that although the impact of price volatility to slaughter rate is not significantly high, but it can be a solution to increase the population and production of beef in the future.

The quantity of imported beef has the magnitude of -0.018 and it is significantly influenced the slaughter rate $(p<0.10)$ and inelastic. The small value and negative sign indicates that the $10 \%$ increase on the quantity of imported beef in the previous period will decrease the number of cattle being slaughtered by $0.18 \%$. The imported beef will influence the availability of beef as well as demand for beef after a period, while the imported feeder cattle will influence the inventory or stock of beef at least four months later after fattening. Therefore, the increasing quantity of imported beef in this period will decline the number of cattle being slaughtered in the next period.

The statement is supported by Kusriatmi et al. (2014) who find similar sign for direct relationships between imported beef and the production of beef, although with higher magnitude than the one in this study. Zainuddin et al. (2015) use the price of imported beef as the variable influencing supply response of beef and come to similar conclusion that the price of imported beef influences the production of beef indirectly through the quantity of imported beef. The rise in the price of imported beef will decrease the quantity of beef imported and it will subsequently increase the quantity of beef produced locally. The negative relationships between the imported meat from previous period and the current slaughter rate could also be an indication that the imported meat could be a temporary solution to the 
decline of the slaughter rate caused by the price volatility. By importing meat, it is also expected to decrease the volatility of beef price.

It is interesting to understand the fact that producers or farmers are more responsive to different changes in the market including the price and price volatility. However, Zainuddin et al. (2015) found different results. Zainuddin et al. (2015) illustrate how producers are responsive to the changes in non-market factors, such as the price of milk and the price of poultry. However, Zainuddin et al. (2015) seemed to assume that farmers were risked neutral and did not include risk price variable in the supply response equation.

The parameter coefficients of the slaughter number in the previous period contained a coefficient value of $\beta$ around 0.088. Gosalamang et al. (2012) found a higher coefficient value of $\beta$ with the magnitude of the adjustment coefficient of 0.143 . According to Gosalamang et al. (2012), the coefficient adjustment close to zero indicates the slow adjustment of farmers to the demand and supply shocks.

The low adjustment coefficient implies that beef farmers in Indonesia adjust slowly to changes in demand and supply shocks or both economic and technical factors. Rusdianto et al. (2015) are supported the argument. Through their research, it was found that the price of beef cattle could not influence the number of beef cattle ready to slaughter because it took time to fattening the cattle. According to Harmini et al. (2011), the process of fattening cattle from local breed takes three years. Fikar and Ruhyadi (2012) add by saying that it takes three to four months for the imported feeder cattle to be ready to slaughter. This also justifies the important of imports to fulfill the demand for beef that is increased every year, specifically for the microscale beef processing industry. The industry could not just stop because of the increased in price or price volatility. However, the effort to improve local cattle reproduction is still important to achieve beef self-sufficiency.

According to the facts previously mentioned above, it is clear that price volatility could be an important risk factor for beef supply in Indonesia. Therefore, price stabilization is important, and the use of hedging mechanism is a necessity to reduce the loss caused by the risk and uncertainty. To increase the population of cattle in the long term, productive female cattle have to be retained and added. This could be done by decreasing the slaughter rate through maintaining high consumer price, and increasing the import of meat. It is recommended for the Indonesian Government to be involved in the process of importing meat and distributing the imported meat through BULOG (Indonesian Bureau of Logistics). The distribution of imported meat and the management of price by BULOG could also prevent volatility. The profit earned by BULOG as state-owned enterprise could be allocated to empower the farmers to become commercial farmers. However, it is also important to increase the capacity of BULOG in beef marketing industry as well as to consider the market shares and the position of Bulog in the imported meat industry, and the important involvement of other agencies such as Ministry of Trade and Ministry of Agriculture in the import regulation and the transfer of BULOG's profit to the community.

\section{CONCLUSION}

The GARCH $(2,3)$ is appeared to be particularly appropriate to describe the beef price supply response. Beef price volatility in Indonesia was found to be low and persistent in the long run. Price uncertainty appears to have a substantial negative effect on Indonesian beef production. The slow adjustment of farmers to demand and supply shocks indicate the importance of import as a temporary policy to fulfill the demand of beef in the short and medium-run.

\section{CONFLICT OF INTEREST}

Authors clarify that there is no conflict of interest with any financial, personal, or other relationships with other people or organization related to the material discussed in the manuscript.

\section{ACKNOWLEDGEMENT}

The authors gratefully acknowledge the support of the Southeast Asian Regional Center for Graduate Study and Research in Agriculture (SEARCA) for funding this research. The authors would like to thank the Ministry of Agriculture, Ministry of Trade, and the Bureau of Central Statistics for generously sharing their price data for beef, import volume, and other data.

\section{REFERENCES}

Ajetomobi, J.O. 2010. Supply response, risk and institutional change in Nigerian Agriculture. African Economic Research Consortium (AERC) Research Paper 197. https:// www.africaportal.org/documents/6442/RP197.pdf [02 March 2017].

Ariningsih, E. 2014. Performance of national beef self-sufficiency policy. Forum Penelitian Agro Ekonomi 32:137-156. https://doi.org/10.21082/fae.v32n2.2014.137-156

Bhattacharya, P., B. N. Rath, \& A. K. Dash. 2016. Supply response of milk production: analysis and implications for BRIC Countries. Applied Econometrics and International Development 16:179-192.

Bollerslev, T. 1986. Generalized autoregressive conditional heteroskedasticity. J. Econom. 31:307-327. https:/doi. org/10.1016/0304-4076(86)90063-1

Burhani, F. J., A. Fariyanti, \& S. Jahroh. 2013. Analisis volatilitas harga daging sapi potong dan daging ayam broiler di Indonesia. Forum Agribisnis 3:19-39.

Ehirim, N. C., U. S. Okoro, E. Ikheloa, L. O. E. Nwauwa, I. J. Onwuagba, \& C. Mgbeojirikwe. 2017. Soybean supply response to price and non-price factors in Nigeria: Implications for food security. Asian Journal of Agricultural Extension, Economics \& Sociology 15:1-10. https://doi.org/10.9734/AJAEES/2017/8261

Fikar, S. \& D. Ruhyadi. 2012. Penggemukan Sapi 4 Bulan Panen. Agromedia Pustaka, Jakarta.

Gosalamang, D. S., A. Belete, J. J. Hlongwane, \& M. Masuku. 2012. Supply response of beef farmers in Botswana: a nerlovian partial adjustment model approach. Afr. J. Agric. Res. 7:4383-4389. https://doi.org/10.5897/AJAR11.2008

Harmini, R.W. Asmarantaka, \& J. Atmakusuma. 2011. Model 
dinamis sistem ketersediaan daging sapi nasional. Jurnal Ekonomi Pembangunan 12:128-146. https://doi. org/10.23917/jep.v12i1.211

Ilham, N. 2009. Kebijakan pengendalian harga daging sapi nasional. Analisis Kebijakan Pertanian 7:211-221.

Kalangi, L.S., Y. Syaukat, S.U. Kuntjoro, \& A. Priyanti. 2014. Technical efficiency of beef cattle breeding business in East Java Province. Med. Pet. 37:136-142. https://doi. org/10.5398/medpet.2014.37.2.136

Komalawati, R.W. Asmarantaka, R. Nurmalina, \& D.B. Hakim. 2018. Dampak volatilitas harga daging sapi terhadap industri pengolahan daging sapi skala mikro di Indonesia. Jurnal Pangan 27:9-24.

Kusriatmi, R. Oktaviani, Y. Syaukat, \& A. Said. 2014. Analysis of the effects of beef import restrictions policy on beef selfsufficiency in Indonesia. J. ISSAAS 20:115-130.

Kuwornu, J. K. M., P. M. I. Maanikuu, Y. B. Osei-Asare. 2011. Supply response of rice in Ghana: A co-integration analysis. Journal of Economics and Sustainable Development 2:1-14.

Leaver, R. 2004. Measuring the supply response function of tobacco in Zimbabwe. Agrekon 43:113-129.

Narundhana, D., R. Tawaf, \& H. Arief. 2016. Faktor-faktor yang mempengaruhi pemotongan sapi impor di rumah potong hewan (RPH) Pemerintah Kota Bandung. Students e-Journal 5:1-10.

Ozkan, B., R. F. Ceylan, H. Kizilay. 2011. Supply response for wheat in Turkey: A vector error correction approach. New Medit. 2011:34-38.

Pambudy, R. 2018. The development of adopting innovation on entrepreneurship status of Madura cattle farmers. Trop. Anim. Sci. J. 41:147-156. https://doi.org/10.5398/ tasj.2018.41.2.147

Prastowo, N.J., T. Yanuarti, \& Y. Depari. 2008. Pengaruh distribusi dalam pembentukan harga komoditas dan implikasinya terhadap inflasi. Working Paper WP/07/28. Bank Indonesia, Jakarta.

Pusdatin. 2016. Outlook Daging Sapi Komoditas Pertanian Subsektor Peternakan. Pusat Data dan Sistem Informasi Pertanian Sekretariat Jenderal Kementerian Pertanian, Jakarta.

Rahji, M. A. Y. \& M. O. Adewumi. 2008. Market supply response and demand for local rice in Nigeria: implications for self-sufficiency policy. Journal Central European of Agriculture 9:567-574.

Rezitis, A. N., \& K. S. Stavropoulos. 2009. Modeling pork supply response and price volatility: the case of Greece. Journal of Agricultural and Applied Economics 41:145162. https://doi.org/10.1017/S1074070800002601

Rezitis, A. N., \& K. S. Stavropoulos. 2010. Modeling beef supply response and price volatility under CAP reforms: The case of Greece. Food Policy 35:163-174. https://doi. org/10.1016/j.foodpol.2009.10.005

Rusdianto, S.W., H.K.S. Daryanto, Kuntjoro, \& A. Priyanti. 2015. Pengaruh perubahan harga sapi terhadap permintaan input dan penawaran output usaha penggemukan sapi bali. Informatika Pertanian 24:223-232. https://doi. org/10.21082/ip.v24n2.2015.p223-232

Tsueoa, T., Y. Syaukat, \& D.B. Hakim. 2012. The impact of the Australia and New Zealand free trade agreement on the beef industry in Indonesia. J. ISSAAS 18:70-82.

Uchezuba, D. I. \& S. Mbai. 2016. Modelling price expectation and volatility effects on producer behaviour: A case of Namibian Beef market. International Journal of Applied Agricultural Research 11:83-102.

Zainuddin, A., R.W. Asmarantaka, \& Harianto. 2015. Perilaku penawaran peternak sapi di Indonesia dalam merespon perubahan harga. Jurnal Agribisnis Indonesia 3:1-10. https://doi.org/10.29244/jai.2015.3.1.1-10 